\title{
Counseling Psychology in Schools: Prevention and Early Intervention for Child and Adolescent Mental Disorders
}

ISSN: 2578-0042

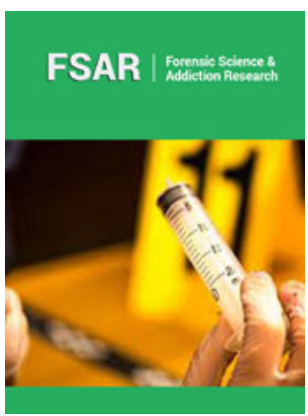

*Corresponding author: Keith Klostermann, Medaille College, USA

Submission: 地 June 10, 2019

Published: 泚June 19, 2019

Volume 4 - Issue 5

How to cite this article: Theresa M, Keith $\mathrm{K}^{*}$ and Melissa M. Counseling Psychology in Schools: Prevention and Early Intervention for Child and Adolescent Mental Disorders. Forensic Sci Add Res. 4(5). FSAR.000603.2019.

DOI: 10.31031/FSAR.2019.04.000603

Copyright@ Keith Klostermann, This article is distributed under the terms of the Creative Commons Attribution 4.0 International License, which permits unrestricted use and redistribution provided that the original author and source are credited.

\author{
Theresa Mignone ${ }^{1}$, Keith Klostermann ${ }^{2 *}$ and Melissa Mahadeo ${ }^{2}$ \\ ${ }^{1}$ Enlightened Therapies of Western New York, USA \\ ${ }^{2}$ Medaille College, USA
}

\section{Editorial}

Given increasing demands at school, coupled with increasing violence and home and school, more and more students are displaying symptoms of anxiety and depression, and at increasingly earlier ages. In response to these challenges, counseling and clinical psychologists have argued for a paradigm shift away from the traditional educational/school psychology model to providing more comprehensive services focused on school-based family treatments as well as testing students' ability and psychological functioning [1] the goal of this shift is to better meet the academic, emotional, social needs of $21^{\text {st }}$ century students. This shift is not merely an academic exercise but a critical step in student support services. Although the typical strategy is to refer these students and their families into the community for help, his approach is limited due to because many families do not follow-up on the referral, services provided may not meet individual/family need, and agency clinicians may not be skilled enough to best help families in crisis. As such, there is a need for increased school-based wraparound services that can meet the comprehensive needs of students (and their families) who are struggling [2]. More specifically, there is a need for school-based experienced, seasoned clinicians with advanced level training in evidence-based practices. Psychologists in this role will be skilled enough to work with individual students and their families, gathering information via testing to identify areas of concern or pathology to further inform treatment and individual education plans, even in crisis situations. By providing this type of service, schools are likely to yield improvements across a number of important domains including, but not limited to, individual student adjustment, family functioning, academic performance, disciplinary referrals, out of school placements, and more timely identification of issues. We also believe that a seasoned and highly skilled clinician who is a member of the faculty will help improve follow-through with treatment recommendations, and that it will have subsequent implications for retention, and by extension, academic outcomes.

\section{References}

1. Bartell R (1996) Changing the role of school psychologists: School-family partnership. Canadian Journal of School Psychology 11(2): 133-137.

2. Eber L, Nelson CM, Miles P (1997) School-based wraparound for students with emotional and behavioral challenges. Exceptional Children 63(4): 539-555. 